Review Article

\title{
Tectonics and Evolution of the Trans-Himalayan Mountains and Nagaland Ophiolite Belt
}

\author{
AK JAIN ${ }^{1, *}$ and S K BHOWMIK ${ }^{2}$ \\ ${ }^{1}$ CSIR-Central Building Research Institute, Roorkee, India \\ ${ }^{2}$ Department of Geology and Geophysics, Indian Institute of Technology, Kharagpur, India
}

(Received on 25 April 2016; Accepted on 30 May 2016)

\begin{abstract}
Scientific investigations in the Trans-Himalayan and Nagaland ophiolite belt during the period 2011-2015 incorporated various geological and geophysical aspects of evolution of these mountains, including large-scale tectonics of the Indian Plate, its sub-surface configuration, structure and metamorphism. Certain remote areas of Karakoram along the upper Shyok valley and Nagaland were covered for their metamorphism and high pressure metamorphism of ophiolite belts, respectively.
\end{abstract}

Keywords: India-Asia Convergence; Tectonics-Trans-Himalaya and Karakoram Mountains; Nagaland Ophiolite Belt; Metamorphism; Geometry of Indian Plate

\section{Introduction}

Since the postulation of Himalayan orogen as a product of continent-continent collision between Atlantic-type margins of the Indian and Asian Plates, many authors have opined that the Himalaya and adjoining TransHimalaya evolved through many other alternative models. Southern margin of the Asian Plate was separated by vast Paleo- and Neo-Tethys Ocean from the Indian continental lithosphere - the region now constitute the Himalaya, Trans-Himalayan LadakhKarakoram Mountains and Tibet Plateau. As the Indian Plate converged anti-clockwise northwards towards Asia since $80 \mathrm{Ma}$, its Neo-Tethyan oceanic floor subducted to produce intra-oceanic Shyok-Dras Volcanic Arc. Between this arc and the Asian Plate, a thick Paleo-Mesozoic Karakoram sedimentary sequence was deposited on the southern Asian margin. This ocean closed along the Shyok Suture Zone (SSZ) in the north and the Indus Tsangpo Suture Zones (ITSZ) towards south, which demarcate the contact between the two plates. These sutures preserve evidences of (i) an initial Late Mesozoic subduction of the Neo-Tethys oceanic lithosphere along the SSZ during the Early Cretaceous?-Lower Eocene with intervening intra-oceanic Shyok-Dras Volcanic Arc, (ii) emplacement of the younger calc-alkaline TransHimalayan plutons to the south of SSZ, and (iii) final closure of the Neo-Tethys along the ITSZ. Further northeast enormously thick obducted Nagaland ophiolites witnessed evidences of HP metamorphism.

Various National groups investigated the Tectonics and evolution of the Trans-Himalayan Mountains individually or in collaboration with many International groups during 2011-2015. Their scientific achievements are recorded here under the following topics: (i) Geometry of the Indian Plate (IP), (ii) Tectonics, stratigraphy and metamorphism of the Karakoram metamorphics, (iii) Vorticity and kinematics of the Karakoram Shear Zone, (iv) Shyok Suture (SSZ) and Indus Tsangpo Suture Zones (ITSZ), and (v) High pressure metamorphism (HP) metamorphism of the Nagaland ophiolite belt.

\section{Geometry of the Indian Plate (IP)}

Vast Neo-Tethyan Ocean separated the Indian and Asian Plates and closed along the Shyok and IndusTsangpo Suture Zones (SSZ and ITSZ) during late Mesozoic, hence these plates did not initially collide with each other (Jain, 2014, 2016). Instead, subducted

\footnotetext{
*Author for Correspondence: E-mail: himalfes@gmail.com
} 
Tethyan oceanic lithosphere in front of the Indian continent partially melted to produce the calc-alkaline suite of the Shyok-Dras volcanic arc. The Indian plate initially subducted beneath and started building up the then existing intra-oceanic island arc. Its subduction and melting beneath the Asian Plate followed to produce the Karakoram Batholith. The Ladakh Batholith subsequently intruded this volcanic arc. The Indian continental lithosphere first approached the trench of the ITSZ and subducted steeply to undergo the ultra-high pressure (UHP) metamorphism at $\sim 53$ Ma (Fig. 1A). Comparison of bulk ages from the Ladakh Batholith (product of partial melting of the Tethyan oceanic lithosphere) with the subducted continental lithospheric and UHP metamorphosed Indian crust in the Tso Morari across the ITSZ provided better constraints on the India-Asia convergence at $\sim 58 \mathrm{Ma}$ (Jain, 2014).

Exhumation of the UHP metamorphosed Tso Morari terrane from nearly 100 to $70 \mathrm{~km}$ depth between 53 and 50 Ma records first emergence of the Himalaya. Repeated sequential subduction, extensive deformation and imbrication of the Indian continental lithosphere in the Higher Himalayan Crystallines (HHC) followed at $\sim 45-35$ and $\sim 25-15$ $\mathrm{Ma}$ to produce Eo- and Neo-Himalayan metamorphisms and associated exhumation episodes during rise of the Himalayan Mountains from north to the south (Fig. 1A).

Geological and geophysical evidences from the Himalaya and nearby mountains bespeak about steep subduction and imbrication of the Indian continental lithosphere since $\sim 58 \mathrm{Ma}$. It clearly implied that original configuration of the Indian continental lithosphere must have been very different-steeper and imbricated (Fig. 1A) than the present-day subhorizontal geometry. Present-day subhorizontal subduction of the Indian Plate and its episodic northward push along the Main Himalayan Thrust (MHT) has rotated these imbricates to follow the present-day geometry (Fig. 1B; Jain, 2016). A near-subhorizontal slab of this lithosphere subducts beneath the Himalaya, TransHimalaya and Tibet till Bangong-Nujiang Suture (BNS). Overriding scrapped imbricated sequences thrust southwards and deform into the Himalayan crustal wedge. The Bangong-Nujiang Suture (BNS) in Central Tibet witnesses true "collisional" signatures of large-scale opposing vergence of the India-Asia Plates (Fig. 1C).

\section{Tectonics, stratigraphy and metamorphism of the Karakoram metamorphics}

Research publications by Thanh et al. (2011) and Van Buer et al. (2015) deal mainly with evolution of the Karakoram metamorphics in extreme northern parts along the Tangste and Shyok valleys of Karakoram Mountains. In the Pangong metamorphic complex, garnet-kyanite-staurolite gneiss contains porphyroblastic euhedral garnets, kyanite blades and resorbed staurolite, surrounded by muscovite-biotite matrix, associated with a leucogranite layer (Thanh et al., 2011). Two generations of garnet in cores and rims represent two stages of metamorphism with rich $\mathrm{Mn}(\mathrm{XSps}=0.35-0.38$ and poor $\mathrm{Fe}(\mathrm{XAlm}=0.40-0.45)$ garnet cores, whereas rims have reverse patterns. Thanh et al. (2011) have suggested that garnet cores formed during prograde metamorphism in a subduction zone, followed by abrupt exhumation during early collision of the Ladakh arc and Karakoram block. Garnet rims overgrew the Mn-rich cores at ca. $680^{\circ} \mathrm{C}$ and ca. $8.5 \mathrm{~kb}$ during subsequent India-Asia collision when these were subducted to a mid-crustal level. Muscovite from metamorphics and associated leucogranite has consistent K-Ar ages (ca. $10 \mathrm{Ma}$ ), and is closely related to activation of the Karakoram fault in the Pangong metamorphic complex.

Further upstream along the Shyok valley, Van Buer et al. (2015) investigated intersection of two main conjugate right-lateral Karakoram fault and the left-lateral Longmu-Gozha Co fault (an eastward continuation of the Altyn Tagh fault) at western end of the Tibetan plateau. These may be connected by large-scale, east-dipping listric Angmong normal fault system, exposing a wedge of mid-crustal metamorphics in its footwall, which yielded latesyntectonic P-T conditions of $6.4 \pm 1 \mathrm{~kb}$ and $\sim 600 \pm 50^{\circ} \mathrm{C}$. U-Pb zircon ages from granitic dikes are as young as $13.7 \pm 0.2 \mathrm{Ma}$, suggesting that footwall rocks remained hot until late Miocene and were exhumed after this time. Van Buer et al. (2015) inferred $>40 \mathrm{~km}$ heave across the Angmong fault, and suggested that it absorbed all the slip across the Longmu-Gozha Co fault, and thus is seemingly confined to the upper crust. 

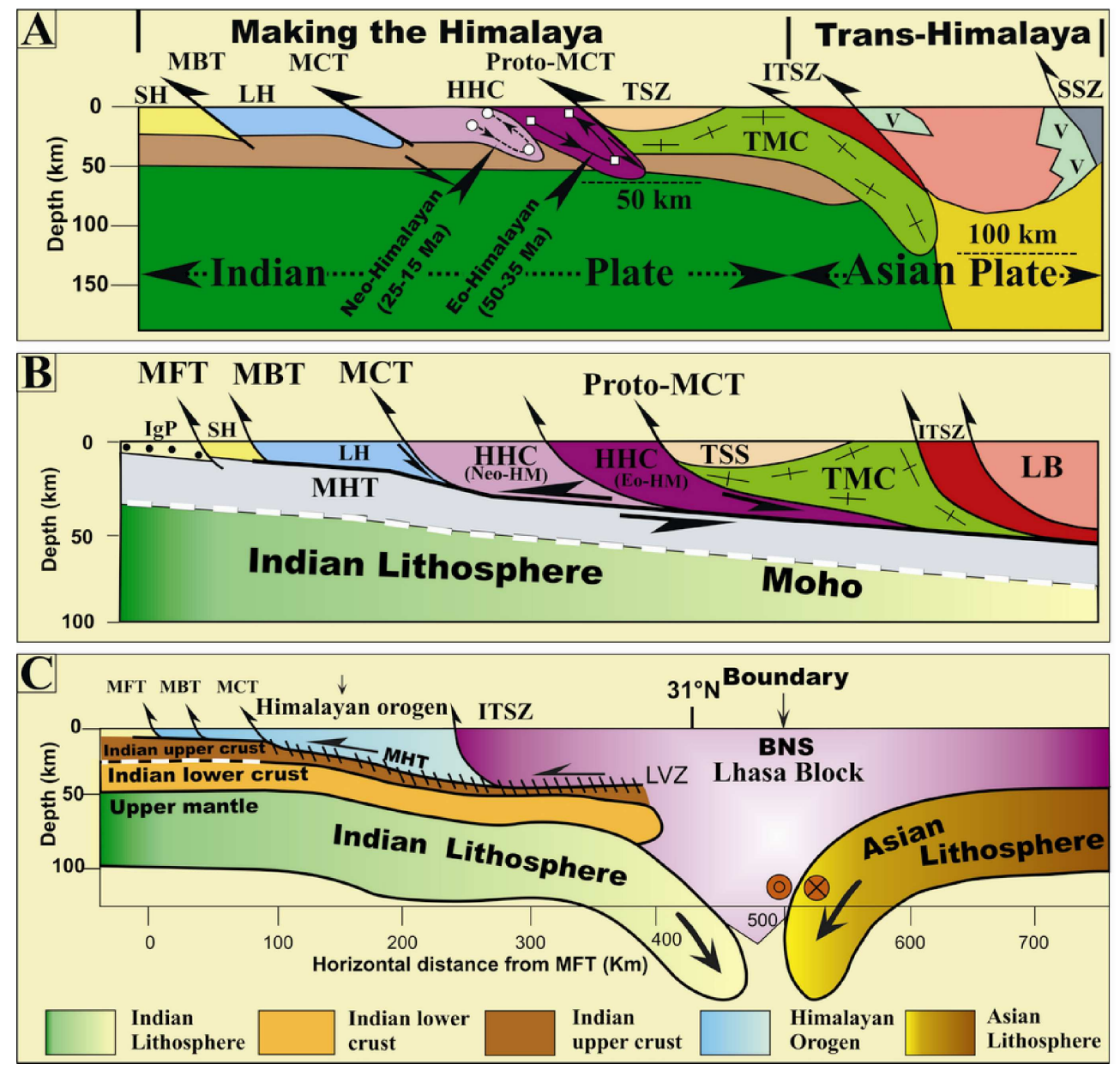

Fig. 1: Simplified geological cross-sections across the Himalaya and Trans-Himalaya showing their evolution through time. (A) Continental subduction in the NW-Himalaya. Shallower and younger continental subduction in the HHC produced peak Eocene ( 48-45 Ma) Eo-Himalayan and pre-MCT metamorphism in upper amphibolite facies. Younger NeoHimalayan Miocene 25 Ma metamorphism, anataxis and leucogranite generation between 25 and 15 Ma. Major discontinuities within HHC caused its differential exhumation. See Jain (2016) for details. Thrusting and imbrication along the MBT and MFT during late Miocene-Pleistocene. (B) Rotation of imbricated slices of the Himalayan Metamorphic Belt (HMB) to gently-dipping crustal wedges of the Tso Morari Crystallines (TMC), Higher Himalayan Crystallines (HHC) including its Higher Himalayan Discontinuities (HHD) by northward push from the subducting Indian continental lithosphere along the Main Himalayan Thrust (MHT) since post-15 Ma. Present-data magnetotelluric data from Garhwal and Ladakh-Karakoram constraint this configuration. The MHT approximately follows upper?lower continental crust boundary. The Indian Lithosphere shown by green-yellow shades, and Moho follows its upper contact. (C) Large-scale tectonics of the Himalayan orogen as a scrapped crustal wedge above the Main Himalayan Thrust (MHT). The Indus Tsangpo Suture Zone (ITSZ) delimits the Himalayan orogen. Simplified geophysical cross-section of the India-Asia convergence beneath the Himalaya and Tibet from the Himalayan-Tibetan Continental Lithosphere During Mountain Building (Hi-CLIMB) profile, depicting "collision" between two plates in the Bangong-Nujiang Suture (BNS). See Jain (2016) for further details

\section{Karakoram Shear Zone (KSZ)}

NW-SE trending dextral ductile Karakoram Shear Zone (KSZ) has mylonitized the Tangste and Darbuk granitoids along the southern margin of the Asian plate. To visualize the overall deformation of the KSZ, Roy et al. (2016) performed kinematic vorticity (Wk) analysis of mylonitized Tangste granite, using Porphyroclast Hyperbolic Distribution (PHD) method on well-developed quartz and feldspar porphyroclasts, and Shear Band (SB) Analysis of synthetic and antithetic shear bands, respectively. The PHD and $\mathrm{SB}$ analyses yield $\mathrm{Wk}$ values ranging from $\mathrm{Wk}=0.29$ 
to 0.43 and 0.45 to 0.93 , respectively, thus indicating distinct pure and simple shear dominant regimes during different stages of evolution of the KSZ. Strain has essentially been pure shear when southern edge of the Asian plate was initially juxtaposed against the Indian plate around $70 \mathrm{Ma}$, and changed to simple shear, possibly during reactivation of this shear zone during 21-13 Ma to produce the shear bands.

In the eastern parts of Karakoram, dextral Karakoram Fault Zone (KFZ) bifurcates into the Pangong and the Tangtse Strand making the Pangong Transpression Zone (PTZ), which exposes the migmatitic dioritic gneiss, calc-silicates and the twomica leucogranite Durbuk Pluton (Sen et al., 2014). Syn-kinematic relationship exists between deformation, leucogranite magmatism and emplacement of the Darbuk Pluton, as is evidenced from parallel magnetic fabric from both tectonized and undeformed parts of this pluton and pervasive melt migration along the KFZ. A genetic link is established between migmatite leucosome from mixed zone and felsic granite in Darbuk where partial melting, with or without segregation of initial melts, seems to be main cause for generation of felsic melts (Rao and Daga, 2015). Felsic partial melts as leucosome were retained in partially molten migmatite zone, and that the complex intrusive networks of melt channels in migmatite region are considered to merge and coalesce during their ascent to upper crustal levels resulting in stocks and plutons of felsic granite that are observed in this region.

$\mathrm{U}-\mathrm{Pb}$ zircon age from dioritic gneiss yields its crystallization at $63.6 \pm 1.5 \mathrm{Ma}$ (Sen et al., 2014) and also shows younger zircon growth down to $\sim 13 \mathrm{Ma}$, which suggest arc magmatism at $\sim 65 \mathrm{Ma}$ followed by partial melting and leucogranite magmatism in the KFZ till 13 Ma. One sample of two-mica leucogranite from the Darbuk Pluton gives a crystallization age of $22.7 \pm 0.5 \mathrm{Ma}$. As this pluton is syntectonic with deformation along the KFZ, it is inferred that the KFZ initiated at least $23 \mathrm{Ma}$ ago.

The shear zone at Tangtse exhibits superposition of high-temperature deformation by low-temperature deformation in mylonitic leucogranite (Mukherjee et $a l ., 2012$ ), and exhibits fluid immiscibility between brine and carbonic inclusions in oscillatory-zoned plagioclase, indicating that they were trapped during the formation of leucogranite. Eventually, these fluids recorded a near-isobaric drop in temperature down to $\angle 450^{\circ} \mathrm{C}$ at amphibolite-greenschist facies transition, when zone of fluid mixing was established. ${ }^{40} \mathrm{Ar}-{ }^{39} \mathrm{Ar}$ biotite ages indicate that rocks cooled down to 400$350^{\circ} \mathrm{C}$ over 10.34-9.48 Ma coinciding with a major phase of fluid infiltration and trapping of secondary re-equilibrated carbonic and saline-aqueous inclusions (Mukherjee et al., 2012). This period recorded a lowtemperature deformation in greenschist conditions, when fluids evolved followed a near-isobaric path at $\sim 2 \mathrm{~kb}$. Subsequently, sudden drop in pressure (1.75$0.5 \mathrm{~kb}$ ) between 9.80 and $9.48 \mathrm{Ma}$, produced reequilibrated fluid inclusion textures. These observations suggest that the KFZ shows single progressive deformation event with bimodal fluid evolution, in which carbonic- and brine-rich inclusions were available prior to high temperature deformation during initiation of the KFZ. Trapping of secondary inclusions between 10.34 and 9.48 Ma with pressure decrease of $\sim 2-0.5 \mathrm{~kb}$ yields an average uplift rate of $1 \mathrm{~mm} / \mathrm{yr}$ for this zone.

\section{Shyok Suture Zone (SSZ)}

Upadhyay (2014) found a 200 m thick limestone sequence, overlying volcanic rocks of the island arc affinity from the SSZ within the larger Saltoro Formation and identified it as a carbonate platform margin with build-ups. Partially recrystallized reefal limestone contains abundant rudists, echinoid spines, gastropods, algae and rich orbitolinid assemblage, which reflects shallow-water tropical environment, having a close affinity with the Yasin Group along the Northern Suture Zone in Kohistan, NW Pakistan. The rudist fauna from both sites resembles the association from the Yasin Group. The presence of Late Aptian Horiopleura, Radiolitidae and different forms of Orbitolina and other microfaunal assemblages in the Saltoro reefal limestone dates the underlying volcanic edifice as middle Cretaceous or older. Rudists, nerineids, corals and foraminifers of Early-Middle Cretaceous age are widely distributed as reefal frameworks all along the tropical and subtropical EuroAfrican-Asiatic regions of northern and southern margin of the Tethys. However, rudist build-ups may also occur far from continental margins, associated with volcanic edifices like in the Caribbean, Sicily, and seamounts in the central Pacific region or, in our cases, volcanic arcs within the Tethys. 


\section{Trans-Himalayan Ladakh Batholith}

The Trans-Himalayan Ladakh Batholith dominantly consists of calc-alkaline I-type granitoids, which are ferromagnetic due to magnetite as the principal carrier of magnetic susceptibility (Sen and Collins, 2013). Mesoscopic and magnetic fabric trend concordantly from WNW-ESE to WSW-ENE for different intrusions of ferromagnetic granites, and is roughly parallel to regional trend of the batholith and orthogonal to direction of India-Eurasia collision. In Khardung La and Chang La sections, this fabric is sigmoidal, which is caused by oblique convergence between the two plates. U-Pb zircon geochronology of rhyolite from southern parts gives a crystallization age of $71.7 \pm 0.6$ $\mathrm{Ma}$, while S-type two-mica granite in central parts is $35.5 \pm 0.5 \mathrm{Ma}$; these bodies have magnetic fabric at a high angle to the regional trend of the batholith (Sen and Collins, 2013). It is proposed that these two-mica granites were emplaced well after cessation of subduction and arc magmatism along fractures that developed perpendicular to the regional strike of the batholith due to shearing.

\section{Indus Tsangpo Suture Zone (ITSZ)}

\section{Zildat Ophiolitic Mélange}

A rock suite of fragmented oceanic metasediments and ophiolite remnants, called as the Zildat Ophiolitic Mélange (ZOM), is sandwiched between the Zildat fault adjacent to the Tso Morari Crystalline (TMC) dome and the Nidar Ophiolitic Complex along the Sumdo-Mahe bridge section of the ITSZ (Sen Koushick et al., 2013). Carbonates lenses and megaclasts range from $100 \mathrm{~m}$ to few $\mathrm{cm}$ in size in which calcite microstructures vary with decreasing temperature and increasing deformation. $\delta^{18} \mathrm{O}$ and $\delta^{13} \mathrm{C}$ isotope values in carbonates show bimodal nature from deeper (interior) to shallower (marginal to Zildat fault) parts. Carbonate blocks from deeper parts of the mélange reflect marine isotopic signatures with limited fluid-rock interaction, which later on provide a mixing zone of oceanic metasediments and/or hydrated ultramafic rocks. At shallower depths of the mélange, carbonates show dominance of syndeformation hydrous fluids, which has been modified later by metamorphism of the adjacent TMC gneisses. Above observations reveal that the ZOM was emplaced over the subducting Indian plate and later on synchronously deformed with the TMC gneissic dome (Sen Koushick et al., 2013).

\section{Indus Group}

The Indus Group sediments were deposited in an actively subsiding Indus Basin of the ITSZ in Ladakh after the India-Asia collision. This basin represents closure of the Neo-Tethys Ocean in a narrow relict embayment of a shallow sea with prominent tidal energy, and received sediments from northern source in the Ladakh Batholith and Karakoram block as well as from the south, i.e. the Indian continental margin and Suture zone deposits (Singh et al., 2015). Tectonic pulses in north as well as south contributed coarse sediments as conglomerates during its deposition, which took place in tidal flat and sand-shoal complexes under the influence of moderate tidal energy and weak wave energy. In the areas of point sources in the basin, alluvial fans built braid plains extending into the basin. Due to Indian-Myanmarese (Burmese) plate collision the basin closed in the east, but it remained open in the west and connected to a diminishing NeoTethys Ocean. Most of the fossil records in the Indus Group are freshwater plants, land vertebrates, freshwater molluscs and ostracods from conglomerate deposits of the braid plain, indicating that the basin received huge amounts of freshwater and detritus from landmasses in the north and the south. The age of the Indus Group sediments is estimated to be from 41 Ma to $20 \mathrm{Ma}$, though no precise biostratigraphic and chronostratigraphic controls are available. Inversion of the basin resulted in upliftment over the Ladakh Batholith around $20 \mathrm{Ma}$. Deposition of the Indus Group is almost contemporary with the deposition of the Sirmur Group, particularly the Dagshai-Kasauli formations, of the Lesser Himalaya (Singh et al., 2015). It is postulated that deposition in both the areas was controlled by same geotectonic processes of the Himalaya.

\section{Nagaland Ophiolite Complex (NOC)}

The Nagaland Ophiolite Complex (NOC) is the largest exposed section of a suite of ophiolitic rocks in the Indo-Burmese Ranges (IBR) that are part of a 3000 $\mathrm{km}$ long, nearly N-S-trending, arcuate ophiolite belt from the eastern Himalayan syntaxis in the north through the IBR in the middle (Fig. 2A) to the Andaman-Nicobar Islands in the south. The IBR ophiolite belt has been proposed to be the eastern extension of the ITSZ that separates the Asian and 
Indian Plates. The ophiolite belt lies between easterly subducting Indian oceanic lithosphere to the west and Jurassic to Cretaceous collage of HP/LT metamorphosed oceanic lithosphere and Jurassic to
Cretaceous magmatic arc-forearc system of the Burmese plate to the east that is separated from the Asian plate by N-S striking Sagaing fault (Fig. 2A).

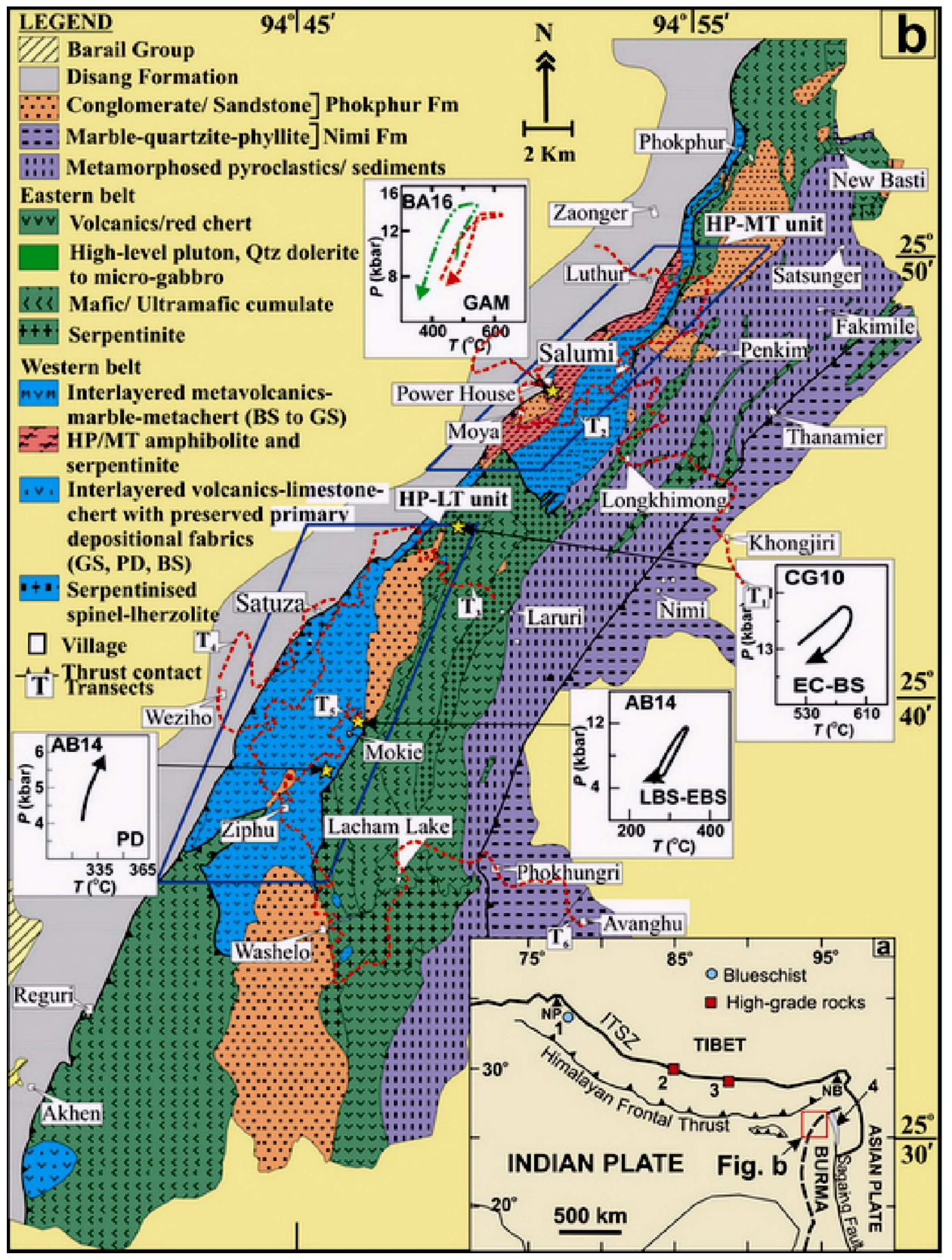

Fig. 2: (A) Simplified tectonic map of the Himalayan orogen in tectonic framework of Indian, Burmese and Asian plates showing locations of blueschist and high-grade rocks along the ITSZ. Rectangular box: Location of the Nagaland Ophiolite Complex (NOC) (Fig. 1B) in the tectonic framework of Indian, Burmese and Asian plates. Abbreviations: NP/ NB, Nanga Parbat/Namche Barwa. Locations: (1) Sapi-Shergol. (2) Saga. (3) Xigaze. (4) Jade Mines Belt. (B) Geological map of the NOC (modified after Anon., 1986) showing locations of pumpellyite diopside (PD), blueschist (BS), eclogite (EC) facies metabasalts and garnetiferous amphibolites (GAM) along with their peak $P$ - $T$ conditions and $P$ - $T$ paths CG10 after Chatterjee and Ghose (2010), (AB14) after Ao and Bhowmik (2014) and BA16 after Bhowmik and Ao (2016). Thick red lines are main road sections 
Previous studies of the NOC indicated preservation of an extremely tectonized ophiolite stratigraphy with pillow basalts and pelagic ocean sediments at the top, followed progressively downwards by sheeted dykes and plagiogranite, cumulate gabbro and a suite of variously serpentinized ultramafic association of dunite, harzburgite, pyroxenite and lherzolite. Preliminary radiolarian biostratigraphic study (Kimmeridgian-lower Tithonian), and whole-rock K-Ar age of basalts (148 \pm 4 Ma) attest an Upper Jurassic age of the Nagaland ophiolites. The ophiolites are thrust to the west over the Disang Formation, a deep marine sequence of cherts, carbonaceous mudstones and fine-grained sandstones of Upper Eocene age (Fig. 2B). The ophiolite sequence is itself non-conformably overlain by an aerially extensive, middle Eocene orogenic molasse deposit, consisting of shallow marine tuffaceous greywackes, conglomerates and shales (cf., Phokphur Formation).

Sporadic eclogite and blueschist occurrences were previously reported in the NOC, where eclogite within the cores of some metabasic lenses (see location in Fig. 2B) is surrounded by successive layers of glaucophane schist, glaucophanite and greenschist (Chatterjee and Ghose, 2010). These authors deduced a prograde clockwise $\mathrm{P}-\mathrm{T}$ path $\left(13 \mathrm{~kb}, 525^{\circ} \mathrm{C}\right)$, peak $\left(17-20 \mathrm{~kb}, 580-610^{\circ} \mathrm{C}\right)$ for the eclogites (Fig. 2B) and post-peak decompression $\left(11 \mathrm{~kb}, 540^{\circ} \mathrm{C}\right)$ metamorphic stages, and proposed retrograde origin for garnetiferous blueschists in outer shells of eclogitic cores.

Ao and Bhowmik (2014) and Bhowmik and Ao (2016) proposed a two-fold classification of the NOC to decipher the anatomy of accretionary wedge and signatures of suture between the Indian and Asian/ Burmese plates (Fig. 2B):

(i) westernmost part of the Nagaland Accretionary Complex (NAC) of a collage of metasedimentary rocks, metabasalts, metagabbros and serpentinites with a range of metamorphic conditions from greenschist through pumpellyite-diopside, blueschist to eclogite facies (Fig. 2B), and

(ii) Nagaland Ophiolite Belt (NOB) of a suite of volcanics, high-level plutons of quartz dolerite to micro-gabbro, mafic and ultramafic cumulates and serpentinites (Fig. 2B) that lack imprints of HP/LT metamorphism.

The HP metamorphic rocks in the NAC occur in two metamorphic sequences of contrasting thermal history: (a) HP/MT (medium temperature) and (b) HP/LT. The HP/MT unit of amphibolites with or without garnet and sodic-calcic pyroxene, exposed near Moya village is polyphase metamorphosed and records two overprinting metamorphic cycles $\left(\mathrm{M}_{1}{ }^{-}\right.$ $\mathrm{M}_{2}$ ), and looping counter-clockwise metamorphic P$\mathrm{T}$ paths as part of a single tectonothermal event (Fig. 2B; Bhowmik and Ao, 2016). The $\mathrm{M}_{1}$ metamorphic cycle records peak metamorphism transitional between amphibolite and hornblende-eclogite facies at $13.8 \pm 2.6 \mathrm{~kb}, 625 \pm 45^{\circ} \mathrm{C}( \pm 2 \sigma)$ and subsequent cooling and partial exhumation to greenschist facies. The $\mathrm{M}_{2}$ metamorphic cycle reflects a second prograde burial to peak metamorphism in epidote blueschist facies condition at $14.4 \pm 2 \mathrm{~kb}, 540 \pm 35^{\circ} \mathrm{C}$ and their final exhumation to greenschist facies condition. Whereas the $\mathrm{M}_{1}$ metamorphism provides the first evidence for initiation of subduction of the Neo-Tethys from eastern segment of the ITSZ, reburial and final exhumation of partially exhumed $\mathrm{M}_{1}$ cycle amphibolites during $\mathrm{M}_{2}$ have been explained in terms of material transport in a large-scale convective circulation system in the subduction channel as the latter evolves from a warm nascent to a cold and more mature stage of subduction (Bhowmik and Ao, 2016).

In the south-western part of the belt, near Satuza-Ziphu-Mokie areas, a tectonized metamorphic sequence of greenschist, pumpellyite-diopside and blueschist facies metabasalts, metacherts and metacarbonates, and belonging to the HP/LT metamorphic unit is exposed (Fig. 2B) (Ao and Bhowmik, 2014). Metabasalts in all the three metamorphic facies have recorded prograde metamorphic overprints directly on primary igneous textures and igneous augite. The blueschist facies body of finely banded lawsonite blueschist and epidote blueschist facies metabasalts and marble has recorded peak $P$ - $T$ conditions at $\sim 11.5 \mathrm{~kb}, \sim 340^{\circ} \mathrm{C}$ and a single cycle, near-complete, hairpin, clockwise $P$ - $T$ loop (Fig. 2B; Ao and Bhowmik, 2014). Apparent low thermal gradient of $8^{\circ} \mathrm{C} \mathrm{km}^{-1}$, corresponding to a maximum burial depth of $40 \mathrm{~km}$ and the hairpin $P-T$ trajectory, were considered as robust evidence for a cold and mature stage of an intra-oceanic subduction zone 
setting for the Nagaland blueschists (Ao and Bhowmik, 2014).

These findings, taken together provide unprecedented new insights into (a) the architecture of a fossil intra-oceanic subduction system within the Neo-Tethys prior to the final suturing between the

\section{References}

Anon (1986) Geology of Nagaland ophiolite Geol Surv India Mem 119 113pp

Ao A and Bhowmik S K (2014) Cold subduction of the Neotethys: The metamorphic record from finely banded lawsonite and epidote blueschists and associated metabasalts of the Nagaland Ophiolite Complex India Jour Metamor Geol 32 829-860

Bhowmik S K and Ao A (2016) Subduction Initiation in the NeoTethys: Constraints from Counterclockwise P-T Paths in Amphibolite Rocks of the Nagaland Ophiolite Complex India Jour Metamor Geol 34 17-44

Chatterjee N and Ghose N C (2010) Metamorphic evolution of the Naga Hills eclogite and blueschist, Northeast India: implications for early subduction of the Indian plate under the Burma microplate Jour Metamor Geol 28 209-225

Jain A K (2014) When did India-Asia collide and make the Himalaya? Current Sci 106 254-266

Jain A K (2016) Continental subduction in the NW-Himalaya and Trans-Himalaya Ital Jour Geosci 135 doi: 10.3301/ IJG. 2015.43

Mukherjee B K, Sen K, Sachan H K and Paul S K (2012) Exhumation history of the Karakoram fault zone mylonites: New constraints from microstructures, fluid inclusions, and ${ }^{40} \mathrm{Ar}-{ }^{39} \mathrm{Ar}$ analyses Lithosphere 4 230-241

Rao D R and Daga M M (2015) Felsic granites vis-à-vis leucosomes from the Shyok-Darbuk section of the Shyok Suture Zone, eastern Ladakh, India: A geochemical study Current Sci 108 198-204

Roy P, Jain A K and Singh S (2016) Kinematic vorticity analysis along the Karakoram Shear Zone, Pangong Mountains, Karakoram: Implications for the India-Asia Tectonics Jour Geol Soc India 87 249-260
Indian and Burmese plates, (b) evolution of the thermal structure of the subduction zone from an initially warm to a later cold and mature stage and (c) the complexity of subduction channel dynamics, involving recurring burial and exhumation cycles involving the first subducted oceanic crust within the Neo-Tethys, which may be more common than presently known.

Sen K and Collins A S (2013) Dextral transpression and late Eocene magmatism in the trans-Himalayan Ladakh Batholith (North India): implications for tectono-magmatic evolution of the Indo-Eurasian collisional arc Int Jour Earth Sci (Geol Rundsch) 102 1895-1909. DOI 10.1007/s00531012-0826-8

Sen, Koushick, Das S, Mukherjee B K and Sen, Koushik (2013) Bimodal stable isotope signatures of Zildat Ophiolitic Mélange, Indus Suture Zone, Himalaya: implications for emplacement of an ophiolitic mélange in a convergent setup Int Jour Earth Sci (Geol Rundsch) 102 2033-2042

Sen K, Mukherjee B K and Collins A S (2014) Interplay of deformation and magmatism in the Pangong Transpression Zone, eastern Ladakh, India: Implications for remobilization of the trans-Himalayan magmatic arc and initiation of the Karakoram Fault Jour Struct Geol 62 1324

Singh I B, Sahni A, Jain A K, Upadhyay R, Parcha S K, Parmar V, Agarwal K K, Shukla S, Kumar S, Singh M P, Ahmad S, Jigyasu D K, Arya R and Pandey S (2015) Post-collision sedimentation in the Indus Basin (Ladakh, India): Implications for the evolution of the northern margin of the Indian Plate Jour Palaeont Soc India 60 97-146

Thanh N X, Sajeev K, Itaya T and Windley B F (2011) Multiple garnet growth in garnet-kyanite-staurolite gneiss, Pangong metamorphic complex, Ladakh Himalaya: New constraints on tectonic setting Lithos 127 552-563

Upadhyay R (2014) Palaeogeographic significance of 'Yasin-type' rudist and orbitolinid fauna of the Shyok Suture Zone, Saltoro Hills, northern Ladakh, India. In: Special Section: Science of the Himalaya Current Sci 106 245-253

Van Buer N J, Jagoutz O, Upadhyay R and Guillong M (2015) Exposure of mid-crust in western Tibet demonstrates mechanical decoupling below plateau-bounding strike-slip faults Earth Planet Sci Lettr 413 144-157. 